\title{
God, the Past and Auschwitz: Jewish Holocaust Theologians' Engagement with History
}

Link to publication record in Manchester Research Explorer

\section{Citation for published version (APA):}

Langton, D. (2011). God, the Past and Auschwitz: Jewish Holocaust Theologians' Engagement with History. Holocaust Studies, 17(1), 29-62.

\section{Published in:}

Holocaust Studies

\section{Citing this paper}

Please note that where the full-text provided on Manchester Research Explorer is the Author Accepted Manuscript or Proof version this may differ from the final Published version. If citing, it is advised that you check and use the publisher's definitive version.

\section{General rights}

Copyright and moral rights for the publications made accessible in the Research Explorer are retained by the authors and/or other copyright owners and it is a condition of accessing publications that users recognise and abide by the legal requirements associated with these rights.

\section{Takedown policy}

If you believe that this document breaches copyright please refer to the University of Manchester's Takedown Procedures [http://man.ac.uk/04Y6Bo] or contact uml.scholarlycommunications@manchester.ac.uk providing relevant details, so we can investigate your claim.

\section{OPEN ACCESS}




\title{
God, the Past and Auschwitz: Jewish Holocaust Theologians' Engagement with History
}

\author{
DANIEL R. LANGTON
}

\begin{abstract}
The Holocaust has provoked a wide variety of Jewish religious responses, some of which include the claim that, ultimately, historical analysis is incapable of explaining the Nazi genocide. Other Jewish religious thinkers have argued that they can trace God's providential action and revelation in history, often drawing heavily upon historical resources including survivor testimonies, court transcripts and other accounts of atrocities. Several have concluded that religious Jews must acknowledge the historical impact of the event, and shed any lingering assumptions about an unchanging essence of Judaism. This article will explore the engagement with history among religious commentators on the Holocaust such as Eliezer Berkovits, Arthur Cohen, Emil Fackenheim, Irving Greenberg, Hans Jonas, Ignaz Maybaum, Melissa Raphael, Richard Rubenstein and Elie Wiesel, as reflected in their writings about the uniqueness of the Shoah, its challenge to Judaism and the covenant, its connection to the State of Israel, and the problem of evil.
\end{abstract}

\section{Introduction}

Jewish scholars have engaged in a number of ways with history in the construction of their religious responses to the Holocaust or Shoah. Here we will consider three kinds of claim that have been made in this context. ${ }^{1}$

Daniel Langton is Professor of the History of Jewish-Christian Relations at the University of Manchester, co-director of its Centre for Jewish Studies, Secretary of the European Association of Jewish Studies, and co-editor of the journal Melilah. He is a historian interested in Jewish-Christian relations and modern Jewish thought and identity and his published works include Claude Montefiore: His Life and Thought (2002), Children of Zion: Jewish and Christian Perspectives on the Holy Land (2008), and The Apostle Paul in the Jewish Imagination (2010). He has also co-edited Writing the Holocaust (2011) and Normative Judaism? Jews, Judaism and Jewish Identity (2012).

Holocaust Studies: A Journal of Culture and History, Vol.17, No.1, Spring 2011, pp.29-62

PUBLISHED BY VALLENTINE MITCHELL, LONDON 


\section{Electronic Offprint}

The first is that the Holocaust was a unique event which has proved inexplicable and beyond the reach of historical enquiry. The second is that the Holocaust provides dramatic evidence of God's action in history. And the third is that the Holocaust demands profound changes in Judaism, which would imply that Judaism is vulnerable to the influence of historical forces - a problematic idea for those who would see it as a collection of timeless, unchanging truths.

It is perhaps worth offering a few definitions in this context. 'The Holocaust' here refers to the systematic, state-sponsored persecution and murder of six million Jews by Germans and their collaborators, led by the Nazis. The scholars we shall discuss are well aware that other ethnic groups such as the Roma, political prisoners such as communists, religious communities such as Jehovah Witnesses, and so-called social deviants such as homosexuals, were swept up in the event. Nevertheless, the primary focus remains firmly on the implications of the catastrophe for Judaism and Jewish identity in terms of the threat to the Covenant between God and the People of Israel, the challenge for scriptural resources, and the link between the Holocaust and the establishment of the State of Israel in 1948. 'Holocaust Theology' is simply shorthand for 'religious or theological responses to the Holocaust' and, although many are Christian, ${ }^{2}$ here we will focus exclusively on Jewish thinkers. Again, although there exist a few examples of religious responses from the actual time in question, ${ }^{3}$ all of the theologies considered here are retrospective and might be better described as post-Holocaust theologies; the earliest dates from 1966 and the latest 2003.

In what follows, the term 'history' will be used in several related senses, including historical method or investigation (i.e. the speculative attempt to synthesise from the fragmentary evidence left to us plausible accounts of what actually happened), the past itself (i.e. events and human affairs in and of themselves), and historicism (i.e. the recognition that one's understanding of the past is profoundly shaped by one's location in a specific historical, social and intellectual setting). It is worth noting that the author's perspective is non-religious and that his understanding of historical method is limited to the idea of a methodologically materialistic or naturalistic endeavour that seeks to make useful generalisations about the past. Insofar as the writing of history can be achieved without 


\section{Electronic Offprint}

recourse to supernatural explanations or factors, it is unlikely to agree with the findings of some Holocaust Theologians, for example, the idea that the historical past demonstrates a self-evident direction of development as if guided by a divine hand. Having said this, no claim is made here for objectivity, and no attempt will be made to offer any kind of systematic critique. ${ }^{4}$ Instead, the focus will be mainly on the specific claims regarding history made by the Holocaust Theologians themselves. Finally, while what follows has been written with an undergraduate readership primarily in mind, it is hoped that there will be insights for scholars more familiar with the sources who are interested in the treatment of history in the writings of Jewish religious thinkers who have engaged with the Holocaust.

\section{The Uniqueness of the Holocaust and the Failure of Historical Enquiry}

A number of prominent Jewish thinkers have argued forcefully that the Holocaust is essentially a mystery. The Reform-trained rabbi and philosopher, Emil Fackenheim (1916-2003), who was rounded up after Kristallnacht in November 1938 and interned at Sachsenhausen, near Berlin, always insisted that it is our response to the Holocaust, rather than any attempt to explain it as such, that is vital for Judaism. For him, a truly authentic response must recognise the particularity and uniqueness of the Shoah. He deplores the fact that Auschwitz is so easily compared with other atrocities such as Dresden or Hiroshima. ${ }^{5}$ For Fackenheim, it is important not to generalise or to deal in abstractions, because, he says, in so doing we do not actually face the event in and of itself, and if we do not encounter it directly we cannot respond to it adequately. ${ }^{6} \mathrm{He}$ demands that we take hold of historical minutiae and individual examples that cannot be rejected as exceptions, aberrations or mistakes, and which manifest altogether unmistakably the horror of the whole. ${ }^{7}$ In particular, Fackenheim spends considerable time and effort demonstrating the irrational motivations of the perpetrators, with the result that the Holocaust is perceived to be an event unlike any other before or since, and beyond rational analysis. Perhaps the most well known expression of its terrible strangeness is his claim that:

Auschwitz is a unique descent into hell. It is an unprecedented celebration of evil. It is evil for evil's sake ... Where else has 
human skin ever been made into lampshades, and human body fat into soap - not by isolated perverts, but under the direction of ordinary bureaucrats ... Resort to theories of suffering-in-general or persecution-in-general permits such investigations to be evaded. Yet even where the quest for explanations is genuine there is not, and never will be, an adequate explanation. Auschwitz is the scandal of evil for evil's sake, an eruption of demonism without analogy; and the singling-out of Jews, ultimately, is an unparalleled expression of what the rabbis call groundless hate. This is the rock on which throughout eternity all rational explanations will crash and break apart ... Resisting rational explanations, Auschwitz will forever resist religious explanations as well. ${ }^{8}$

A second example is that of the eclectic thinker, novelist and publisher, Arthur Cohen (1928-86). His reflections on the Shoah should be understood as part of a wider, explicitly theological programme. According to Cohen, theology 'sets itself but one task: to apprehend and interpret the presence of God in time and history', 9 and he would eventually come to see the Holocaust as key to this discussion and, in fact, as a threat to the entire project. Once again, we hear the assertion:

Thought and the death camps are incommensurable ... the death camps are unthinkable ... [They are] beyond the discourse of morality and rational condemnation ... [They represent] a new event, one severed from the connection with the traditional presuppositions of history, psychology, politics, morality. ${ }^{10}$

The term he alights upon to capture his sense of the Holocaust, and the title of his book, is one that will be familiar to students of religious studies for he calls it the Tremendum, consciously alluding to Rudolph Otto's Mysterium Tremendum. ${ }^{11}$ For Cohen, Otto's idea of the Holy as the awful presence of God, near and present but unfathomable, mysterious and terrifying, is useful for beginning to appreciate the human tremendum, the Holocaust, which was an 'unparalleled and unfathomable ... celebration of murder'. ${ }^{12}$ As he puts it: 'The death camps are a reality which, by their very nature, obliterate thought and the human programme of thinking. We are dealing ... with something completely unmanageable and obdurate ... The death camps are unthinkable [even if] not unfelt. ${ }^{13}$ 


\section{Electronic Offprint}

It is clear that for Cohen the Holocaust surpasses all other events in its extremity and uniqueness. Like Fackenheim, he is obsessed with the theological challenge facing Jews, that is, the problem of how to bridge the chasm that separates them from their pre-Holocaust traditions and worldview, which are, in the face of the tremendum, completely inadequate. ${ }^{14}$ But he also questions the usefulness of analysing the event with the familiar conceptual tools of history or of the political and social sciences, since the Holocaust is so much more than any particular example of war, or religious or social conflict, or genocide. ${ }^{15}$ Its mystery and its alien nature is expressed, in part, by linking the Holocaust to Otto's phenomenological idea of the Holy.

No one goes further than the survivor Elie Wiesel (1928-), in asserting the inaccessibility of the Shoah. As he once put it: 'The Holocaust cannot be described, it cannot be communicated, it is unexplainable. To me it is a mystical event. I have the feeling almost of a sin when I speak about it. ${ }^{16}$ For Wiesel, whose books almost take the form of biographical theology at times, this incomprehensibility has to do primarily with why God had betrayed his people of the Covenant and the divine responsibility for so much suffering. It has to do with the challenges of answering impossible questions such as, Why did you live and not another? But it is also very much a response to those who would seek to explain or to understand the event. The Holocaust and the camps are described as 'the Kingdom of Night', and represent another world, a world that is completely alien to us citizens of the day. He maintains that 'the Event remains unique, unlike any other Product of History, it transcends History'. ${ }^{17}$ Wiesel, who claims to speak as a messenger for the dead, believes that even the survivors do not understand. Having experienced it, they know it, and that knowledge gives them a special status. But they do not understand it. His gaze returns again and again in horrified fascination to the utter incomprehensibility of the lived experience, to the powerlessness of the victims in the face of blind chance. It is this obsession with the subjective experience of the victim that ultimately lies behind Wiesel's resolution to set his face against rational investigation of the Holocaust in general.

They [the survivors] know that they had nothing to do with it [their survival]. The choice had not been theirs. Intelligence, education, intuition, experience, courage - nothing had counted. 
Everything had been arranged by chance, only chance. A step towards right or the left, a movement begun too early or too late, a change in mood of a particular overseer, and their fate would have been different. ${ }^{18}$

Decades after leaving the camps, Wiesel remains profoundly traumatised by the remembrance of the enormity of the consequences of inconsequential actions within the Kingdom of Night. The awful awareness of the abyss that lay beneath the feet of each individual inmate and the dreadful realisation that there was no path one could tread to reach safety, have left their mark. Chaos and madness reigned. Who can blame him for regarding as blasphemous those who believe that such happenings can possibly be explained?

The conviction that the Holocaust frustrates rational analysis and cannot be understood historically has been influential. Wiesel and Fackenheim in particular represent authoritative voices within the Jewish community and are in no small way responsible for the widespread sacralisation of the Shoah more generally. Someone who has taken issue with such a claim is the renowned Holocaust historian Yehuda Bauer. In 'Is the Holocaust Explicable?' (1990) he argues that,

if the Holocaust is totally inexplicable, utterly mysterious ... then it is also outside history, and therefore irrelevant to future generations. Absolute uniqueness then leads to its opposite, namely total trivialization: if the Holocaust is irrelevant because it is a one-time, inexplicable occurrence, then it is a waste of time to deal with it, and had better be forgotten. ${ }^{19}$

To assert that the Shoah is inexplicable is a dangerous, irresponsible position to adopt, for it encourages fatalism, a sense of futility, and an abdication of responsibility for how history unfolds in the real world. Furthermore, while the Holocaust was an extreme case and the first of its kind on several levels, yet most would agree that it could all too easily be repeated, which poses a challenge to those who emphasise its mystery. As Bauer puts it,

We live in an age when Holocausts are possible, though they are not inevitable ... To those who would argue for some mysterious, inexplicable quality of the Holocaust the difficulty then arises that they would have to contend not only with the inexplicability of 


\section{Electronic Offprint}

the Holocaust of World War II, but also with the inexplicability, presumably, of all Holocaust-like events. ${ }^{20}$

Bauer struggles to identify exactly what it is about the Holocaust that defies reason in those theologians, writers and historians who emphasise its inexplicability, observing that

modern authors take good care to state that the inexplicability refers not to the processes that led to the establishment of the Nazi state, or the irrational rationale of establishing ghettoes or concentration camps, but [rather] to some inner quality, expressed by the senseless brutality of the perpetrators, the silence of the bystanders, the stunned reaction of the unsuspecting victims, the vast extent of the crime, the allegedly inexplicable involvement in the crime of very large numbers of a civilized, supposedly Christian nation and millions of willing helpers from among the other European nations. [my italics] ${ }^{21}$

Bauer is only partially accurate in his observations when he suggests that the claim of inexplicability does not relate to any issue with historical processes or any irrational rationale, at least when it comes to religious responses to the Shoah. This is not true of Cohen and Fackenheim, for example, for whom the claim of inexplicability does express a profound scepticism that the causes of the Holocaust can be explained in purely naturalistic terms. And as we shall shortly see, other Jewish theologians do not stop by simply expressing their doubt as the validity of historical method for approaching the Holocaust, but go on to introduce divine action in history as an explanatory factor. Nevertheless, Bauer's idea that proponents of the inexplicability of the Holocaust were trying to articulate some indefinable 'inner quality' of the event, something that ties together the items on his list, is certainly also applicable to Holocaust Theologians. And here he makes a very interesting and insightful observation. If one lists those aspects of the Holocaust that are regarded as indicative of its mystery, they relate almost exclusively to the behaviour of the perpetrators, victims and bystanders. Of course, no-one can truly understand another person's experiences and so human subjectivity is mysterious in this limited sense. But just because one has not committed certain kinds of criminal activities 
does not mean that one cannot understand criminal actions and the motivations that lead to them, precisely because one has experienced similar or equivalent motivations, and because of the power of empathetic imagination. This 'comparability of human experience', as Bauer calls it, is one of the basic foundational assumptions for the writing of intelligible history. ${ }^{22}$ It makes it worthwhile for historians to try to identify the motivations and assumptions of historical personalities in order to construct plausible explanations of historical events. While it might be very difficult indeed to uncover and to articulate precisely the motivations and assumptions lying behind the actions of people living in unfamiliar times and cultures, it is not, in principle, beyond us. If it were, then it is difficult to see how historians could offer accounts of the past that made any sense at a basic level. Assuming that one is prepared to agree that such history is possible, then whatever the immense difficulty in imagining the situations in which perpetrators, victims and bystanders of the Holocaust found themselves, one has to accept that, as humans, their behaviours are explicable to us in a very real sense. Bauer provides an instructive example.

What do we mean when we say that we can place ourselves in the shoes' of Heinrich Himmler? Naturally, most of us will reject such a possibility with disgust: we could never be capable of acting like that. But when we say that, we protest too loudly. The warning contained in the Holocaust surely is that it can be repeated, under certain conditions, by anyone ... In his famous Poznan speech of 4 October 1943, [Himmler] talks openly about the mass murder of the Jews, and then adds that this should never become known. Does he there acknowledge that one will never be able to 'understand' him? I do not think so. Himmler was, after all, not unique in any sense in his murderous intentions, as we have seen. Not to 'understand' him would imply that we cannot 'understand' any parallel or similar event in history, whereas we know already that human history contains legions upon legions of such events ... sadism, brutality, murder of innocent people on a mass scale is nothing new ... [I]f Himmler was a human - and he was - then his motives were human; do we find in ourselves elements of Himmler's motivations that would build enough of a bridge between ourselves and him to enable us to understand him? I would claim that, indeed, we do. ${ }^{23}$ 


\section{Electronic Offprint}

Arguably, a similar approach might be adopted for the victims themselves, whose acquiescence ('like lambs to the slaughter') has often been remarked on, and also for bystanders, including Christians and Jews, whose self-deception and ethical collapse have also provoked much hand-ringing and soul-searching. Although Bauer is correct to see the core of the claim of an inexplicable 'inner quality' of the Holocaust as an expression of bewilderment at human behaviour in extremis, he has overlooked one important feature of the religious or theological responses, which, in this context, is more relevant still. For Jewish thinkers like Cohen, Fackenheim and Wiesel, the Holocaust is historically unique in the sense that it represents a challenge to Judaism or Jewish faith that, they fear, might well be fatal. Central beliefs about the creator-redeemer God, who has made an eternal covenant with the people of Israel, have been profoundly shaken. There is, as Cohen has put it, a chasm that separates Jewish thought before and after the Shoah, and the challenge is how to bridge it. ${ }^{24}$ Fackenheim, as we shall see, can find no rational reason why Jews would want to live on as Jews after Auschwitz. Wiesel's faith is highly fraught, with even God's existence, and certainly His justice, in question. ${ }^{25}$ To the extent to which the Shoah is believed to have shattered the confidence of Jews in the theological foundations of Judaism in a way that no previous historical event has achieved, it is small wonder that the conclusion reached is that it is truly unique and mysterious. But we need to be clear about this. It is the theological challenge that has brought about the conviction that the Holocaust is historically unique and mysterious. The implicit logic is: if an event truly has the potential to deal a mortal blow to Judaism, then it must be an event like no other.

While such Holocaust Theologians assert the impossibility of grappling with the event using the conventional conceptual tools of rational or historical discourse, others believe that they possess the key to its comprehension. They suggest that, actually, what is missing is God, and that once He has been factored in as an historical, causal agent, the Holocaust does make some kind of sense.

\section{The Holocaust and Tracing the Footprints of God in History}

In a number of religious responses to the Holocaust one can find the argument that this event is dramatic evidence of God's action in 


\section{Electronic Offprint}

history, a kind of proof of God's immanence or of His active presence in the realm of human affairs. This is very interesting, considering the reluctance of so many theologians and religious thinkers in modern times to make specific claims about God's activity with reference to specific events in contemporary history. For liberals and progressives in particular, the triumph of historicism, and the privileging of naturalistic, rational interpretations of the past over supernatural, providential ones, has had the effect of removing God from history. Arguably, it has left only religious fundamentalists able to champion a God who intervenes in history and thus who matters in the real world. But after the horrors of the camps, abstract conceptions of the divine seem somehow too distant and inadequate. The desire to believe that such suffering occurs for a reason, and to find solace in some kind of meaning, perhaps even a redemptive purpose, is strong. And the key it seems, at least for some Jewish responses, is to view the Holocaust as part of a pattern of historical events which reveal the guiding hand of divine providence.

One of the earliest attempts to understand the Holocaust as a clear manifestation of God's action in history was that offered by the Reform rabbi, Ignaz Maybaum (1897-1976). A student of Franz Rosenzweig, he saw history as a domain belonging to Christianity, and believed that Israel's mission as a light to the nations was very much one of responsibility rather than privilege. In The Face of God After Auschwitz (1965), he identified three major historical events that threw light on this scheme: these events were, in fact, catastrophes or churbanot. ${ }^{26}$ The destruction of the first temple in 586 BCE by Nebuchadnezzar and the subsequent Babylonian Exile led to a new self-understanding of the Jewish People as a nation without a land, and powerfully facilitated Israel's mission to bring knowledge of God and His Torah to the surrounding nations. The loss of Solomon's Temple and the creation of the Jewish Diaspora, then, brought about spiritual progress for Judaism and for humankind in general, and exactly the same could be said in regards to the second churban, that is, the destruction of the Second Temple by Titus in $70 \mathrm{CE}$. With Herod's Temple gone, the sacrificial cult would be replaced by what would become the fundamental institution of Jewish worship, namely, the synagogue, which was characterised by prayer and study rather than by ritual offerings. In this case, Judaism's spiritual development could be seen to elevate 


\section{Electronic Offprint}

religious consciousness more generally in that the Jews travelling the expressways of the Roman Empire would now teach that God was to be found everywhere, by no means limited to any one geographical location, and that worship was possible without the shedding of blood. The third churban was, of course, the Holocaust. Putting it simply, Maybaum saw it as ridding Judaism of the pernicious influence of medieval Jewish attitudes towards the Law and tradition. He wrote,

It is not merely small isolated groups of our people but the whole of the Jewish people that is now Westernised. We march with the western nations. We can progress. Religiously we emancipate ourselves from the dictate of the din [legal judgment or authority], from a medievally enforced supervision of our religious life, politically we can dismiss the medieval mentality which separated one community from another with walls and towers, making Zionism necessary, but also visible as part of the medieval way of thinking. ${ }^{27}$

Once again, Jewish suffering should be understood as a historical manifestation of the mission of Israel, to bring about spiritual progress in the wider world. Hitler had, like Nebuchadnezzar before him, been as an instrument of the divine will, ${ }^{28}$ but he had also symbolised what was wrong with mankind. After Hitler's war against the Jews, the world, which had been led into the idolatrous worship of technology and a false messiah that made possible such barbarism, would never again trust in the empty promises of authoritarianism, whether theocractic or scientific, nor would it any longer tolerate religious persecution. ${ }^{29}$ For Maybaum, then, Israel's mission was to be regarded as a kind of vicarious sacrifice, a veritable Suffering Servant (Isaiah 53:45: 'surely our diseases did he bear and our pain he carried ... he was wounded for our transgressions, he was crushed because of our iniquity'). Why, though, one might have asked Maybaum, had the sacrifice of six million been necessary? His answer was that the Christian world had not yet come to understand that spiritual progress was possible without death. For Gentiles, he observed sadly, it was the Crucifixion rather than the Akedah or Binding of Isaac that was the dominant model of divine activity in history. Thus for God to rouse the religious consciousness of Christians, to make them live 


\section{Electronic Offprint}

up to their confessed ideals, he had to speak in a language that they would comprehend. As Maybaum put it,

The Golgotha of modern mankind is Auschwitz. The cross, the Roman gallows, was replaced by the gas chamber. The gentiles, it seems, must first be terrified by the blood of the sacrificed scapegoat to have the mercy of God revealed to them and become converted, become baptized gentiles, become Christians. ${ }^{30}$

The martyrdom of the six million was but the most recent episode in the historical manifestation of the mission of Israel, by which God effects the enlightenment of the gentile world. Maybaum argued that it was therefore incumbent upon the Jew to interpret Auschwitz as an awful portent or morphet, so that this providential plan was in fact realised. ${ }^{31}$

Insofar as Maybaum's conception of God features a supernatural deity who constantly thrusts His hand into history in order to make His sovereign will known, it shares a lot in common with the popular conception of the God of the Hebrew Bible and of conservative Jewish tradition. The suffering of individuals and nations is the consequence of the divine wish to educate as well as to punish, and can be achieved by hardening the heart of a Pharaoh or a Hitler. Ironically, in His desire for 'steadfast love and not sacrifice, the knowledge of God rather than burnt offerings' (Hosea 6:6), He is capable of bringing about the ultimate burnt offering, the Holocaust. This basic understanding of a God-who-acts-in-History is shared by others who would attribute the Holocaust to divine wrath and punishment for any one of a range of sins that have resulted in the abandonment of Torah-true Judaism. ${ }^{32}$ It is even possible to understand God's apparently callous treatment of His children and His betrayal of His Covenant with them as a kind of abuse. This is the furious indictment of the novelist and survivor, Elie Wiesel, in his play The Trial of God (1979), where his Jewish protagonist charges God with 'hostility, cruelty and indifference' - and guilt for the deaths of so many innocents. ${ }^{33}$ The Orthodox Jewish scholar David Blumenthal is more explicit, still. His book, Facing the Abusing God (1993), ${ }^{34}$ fully shares with Maybaum the perception of God's control of the minutia of history as demonstrated in the scriptures and in history, even if, like Wiesel, he adopts a very different value- 


\section{Electronic Offprint}

judgement towards the morality of God's actions. For such thinkers, the Holocaust is a deliberate act of God.

Except for the strongest religious stomachs, of course, the idea of God as a divine despot who dominates human history according to callous whim, is unpalatable in the extreme, especially if it is applied to an understanding of the Holocaust. A radically alternative conception of God would be to view Him as an impersonal, utterly transcendent deity, whose interaction with the world and history is intangible and is best described in abstract rather than concrete terms. This is the kind of God more likely to be found in Jewish philosophical or mystical discourse. Arthur Cohen, whose categorisation of the Holocaust as the absolutely unique, inexplicable Tremendum, gave us a tantalising glimpse of a God for whom the language of traditional Jewish theology is inadequate. According to Cohen, 'God is a filament within the historical but never the filament that we can identify and ignite according to our requirements'. Although human free-will threatens to 'obscure, eclipse, burn out the divine element', ${ }^{35}$ this God is 'the mystery of our futurity', ${ }^{36}$ suggesting that He shapes the direction in which history flows and makes possible the potential paths our destiny might follow. Of course, we cannot hope to see evidence of God's interactions with History, since He does not dwell in the Present but in the potentiality of the Future. Another thinker who arrived at a similar solution, albeit by a very different route, is Richard Rubenstein. His book, After Auschwitz (1966), a classic of the genre, proclaims that the God of (Jewish) Tradition is dead. He writes,

Traditional Jewish theology maintains that God is the ultimate, omnipotent actor in the historical drama. It has interpreted every major catastrophe in Jewish history as God's punishment of a sinful Israel. I fail to see how this position can be maintained without regarding Hitler and the SS as instruments of God's will. The agony of European Jewry cannot be likened to the testing of Job. To see any purpose in the death camps, the traditional believer is forced to regard the most demonic, anti-human explosion of all history as a meaningful expression of God's purposes. ${ }^{37}$

Some time later, after much deliberation as to how to resolve this distasteful problem, Rubenstein concluded that only a transcendent, 
mystical understanding of God could avoid the pitfalls of the traditional language (of reward and punishment in covenantal terms) and thus escape culpability for the deaths of the six million. ${ }^{38}$ At around the same time, the philosopher Hans Jonas also became interested in the potential of kabbalab for interpreting the Holocaust. In 'The Concept of God After Auschwitz' (1968), he articulates a conception of creation that shares certain similarities with 'the old Jewish [mystical] idea' of tzimtzum or 'the contraction of the divine being as the condition for the being of a world'. ${ }^{39}$ His theology is focused on a creator who had set in motion the natural laws of physics and biology but who had then withdrawn Himself from the world in order to allow it to develop in freedom from His control. As Jonas sees it, God had 'divested Himself of any power to interfere with the physical course of things' and this fundamental reality means that $\mathrm{He}$ cannot be held accountable for the Holocaust. ${ }^{40}$

Other schemes lie somewhere in between these two poles of a brutal, serial interventionist God and a philosophical or mystical God who does not ripple the surface of history, even if, at some mysterious level, He might direct its course. One example of such a middle way is offered by the modern Orthodox Zionist, Eliezer Berkovits (1908-92), in his books Faith After the Holocaust (1973) and With God in Hell (1979). Once again, we see an attempt to identify a pattern in history and to view the Holocaust as part of this pattern and, once again, the focus is on Jewish history. In contrast to Maybaum, however, Berkovits does not single out the destructions of the First and Second Temples but instead groups them together with other 'major tragic occasions of Jewish history' including the mass murders during the Crusades in the eleventh to thirteenth centuries, the persecutions during the Black Death in the fourteenth century, the decimation of Spanish Jewry in the fifteenth century, the Cossack pogroms in the seventeenth century, and so on. For Berkovits, the Holocaust is unique only in terms of its magnitude. That said, its place in this lachrymose history of the Jews does tell us something important about the nature of divine providence. He suggests,

That the Jewish people has withstood all the barbarous attacks upon it, that it has been able to maintain itself in the midst of deadly enemies, bespeaks the presence of another kind of power, 


\section{Electronic Offprint}

invisibly playing its part in the history of men. The survival of the Jew, his capacity for revival after catastrophes such as had eliminated mighty nations and empires, indicate the mysterious intrusion of a spiritual dimension into the history of man. The more radical the rebellion against the world of the spirit, the greater the hatred against the Jew. The Final Solution was not only to eliminate the Jewish people from history, but through the destruction of Israel it was meant to finalize the defeat of that mysterious spiritual force against which the rebellion was directed. The Nazis were quite correct in believing that if they did not succeed in the elimination of the 'Jewish influence' upon world history, they would also fail in their plans for world conquest. No matter what they said in their official propaganda, they sensed the mysterious nature of that influence, the presence of a hiding God in history. ${ }^{41}$

Thus the survival of the small, beleaguered nation of Israel witnesses to God's hidden presence in history. For Berkovits, this image of a hidden God can be further developed by reference to the biblical idea of hester panim or the hiding of the face. Reinterpreting such verses as Psalm 13:1 ('How long, O Lord? Will You forget me forever? How long will You hide Your face from me?'), he argues that God's creation of humankind necessarily involved free will, with the consequence that suffering is inevitable. From such evil, God must turn His face for, as Berkovits acknowledges, 'While He shows forbearance with the wicked, he must turn a deaf ear to the anguished cries of the violated. ${ }^{32}$ So God refrains from intervention in order to allow us freedom of moral choice. And yet, as Berkovits had already hinted, God can be perceived to act in history in a redemptive capacity, too. The ultimate demonstration of this, and a moment when the eclipse of God seemed to be over and His face could be said to shine upon us, was the momentous establishment of the State of Israel. In 1948, claims Berkovits, 'We have seen a smile on the face of God'. ${ }^{43}$ But he also offered another argument for how God's influence on Jewish history could be detected, namely, that God's apparent absence is a kind of proof of His presence. Here Berkovits suggests a concept of Divine mightiness that consists in self-restraint, such that the extent of God's power is understood in terms of self-control, ${ }^{44}$ which can be 
gauged from the terrible depths to which human depravity can fall when His face is hidden. From this perspective, the Holocaust is an historical proof of the reality of divine providence. The magnitude of the catastrophe that occurred when men were given free rein indicates just how real and vital is the divine stabilising force within human history, and just how much we miss it when it is not there. For Berkovits, then, history is a balancing act between God's self-restraint in allowing human freewill, which can lead to an eclipse of the divine in a catastrophic event such as the Holocaust, and His mercy in occasional intervention, which is neatly exemplified by the rise of the Jewish State of Israel. ${ }^{45}$ If you want to understand the how and why of the Holocaust, says Berkovits, you need to understand the way in which God involves Himself, or tinkers, in Jewish covenantal history.

Fackenheim, too, seems to be attracted by the idea that a proper understanding of Jewish history can throw light on the Holocaust, and that, despite his protestations to the contrary, it can be better comprehended once it is interpreted as a divine intervention, a revelation. He explains that one of the unique characteristics of the Holocaust, for example, is the way in which it combines two kinds of historical category. Fackenheim points to a few 'root experiences', that is, historical events during which God's presence was made manifest, such as when He redeemed His children from Egypt or when He brought down the Law at Mount Sinai, and which represent the extraordinary revelational, covenantal foundations of the Jewish People and their religious identity. ${ }^{46}$ There are also 'epoch-making events', that is, historical moments which challenge the beliefs that are ultimately derived from these revelational foundations of Jewish religious identity, such as the destructions of the Temples. ${ }^{47}$ The Holocaust appears to fit this second category, that of the 'epochmaking event', in that it challenges the traditional beliefs in a redeeming God who commands history, just as had the fall of Solomon's and Herod's Temples. For Fackenheim, however, it is more than this: it has the potential to become formative, to add to the essentials of Jewish faith, and thus could be categorised as a 'root experience'. His reasoning seems to be that, as with previous 'root experiences', God was actually present in Auschwitz, from where a new commandment was issued that has left the religious character of the Jewish People very much altered. There appears to be a tension 


\section{Electronic Offprint}

between Fackenheim's insistence noted earlier that the Holocaust is beyond rational thought, and his proposal here that a historical pattern is repeating itself, revealing something of God's purpose. In this particular case, the content of the divine revelation can be inferred from the behaviour of world Jewry in the post-war period. Fackenheim recounts his momentous discovery that,

while religious thinkers were vainly struggling for a response to Auschwitz, Jews throughout the world - rich and poor, learned and ignorant, religious and non-religious - had in some degree been responding all along ... with an unexpected will to live with, under the circumstances, an incredible commitment to Jewish group survival ... Nothing less will do than to say that a commanding voice speaks from Auschwitz, and that there are Jews who hear it and Jews who stop their ears ... Secular Jews hear it, even though perforce they leave it unidentified. ${ }^{48}$

Fackenheim believed that the Holocaust was thus the historical occasion for what has been described variously as the 614th commandment or the 11th commandment, namely, 'Thou shalt not give Hitler a posthumous victory'. ${ }^{49}$ The significance of this theology is that it makes a claim for divine revelation in recent history. He does not mean this in a metaphorical sense, nor is he defining revelation as some kind of manifestation of human activity, since, as we have seen, he had no theoretical difficulty with pointing to history for evidence of God's actions, and he defined a 'root experience', that category of event that is formative for Judaism, as a public, witnessed, historical event which astonishes, as the result of which one can explicitly make 'the claim that God is present in history'. ${ }^{50}$

While he began his life's work by asserting that no meaning could be found in the Holocaust, his insistence on the need to find an authentic response to the catastrophe, and his shock discovery that Jews remained determined to live on as Jews, led him to the conviction that the Jews were, consciously or not, obeying a divine commandment. Only this supernatural explanation made sense of the historical evidence. This new revelation convinced him that God had been present in Auschwitz, as $\mathrm{He}$ had been at other historical revelations such as Sinai and the Exodus. After all, the failure of historians and others to explain the Holocaust indicated just how 
special an event it was. Here, God is not so much of a serial interventionist, or a tinkerer, but an absentee landlord who has put in one of His rare appearances.

Now, it has been suggested that several of our thinkers are sceptical that the causes of the Shoah could be explained in purely naturalistic terms. Cohen, Rubenstein and Jonas are reluctant to go further than this negative assertion, but Maybaum, Wiesel and Blumenthal certainly have no doubts regarding the divine responsibility. Berkovits and Fackenheim also appear to believe that God, who is acknowledged to act in history, is an integral part of the story, without which any account of the Holocaust, as a historical event, is inadequate and unconvincing. For them, God's presence in history, specifically Jewish history, is tangible and the Holocaust becomes a meaningful demonstration of divine intervention or revelation in history. The obvious implication is that if one can acknowledge this, not only will one begin to understand the twentieth-century Nazi genocide of the Jews, but, just as importantly, one can actually come to view it in a redemptive sense, as a means by which to learn that God is real and that He remains interested in humankind.

The assumption that underlies all these accounts is the idea that propositions about God can be or should be confirmed or disconfirmed by an appeal to empirical events in the world, whether in the present or in the past. But this is a highly problematic assumption. It is difficult to see how one can select certain historical events as evidence for or against God's influence upon history, since it is by no means obvious how one might decide objectively which events constitute legitimate evidence, one way or the other. ${ }^{51} \mathrm{~A}$ catastrophe cannot prove the nonexistence of God any more decisively than a triumph can be used as proof of divine providence. A similar problem faces any attempt to identify a supernatural grand scheme or a trend in history; any one of a vast number of combinations is possible, and many must be inimical to each other. For all of our thinkers the common argument, which is almost regarded as self-evident, is that an exclusive focus on Jewish history will reveal God's presence, and that the Holocaust's enormity suggests an especially promising moment. That there is a problem with trying to use history in this way is strongly suggested by the fact 


\section{Electronic Offprint}

that one of our theologians would see the key pattern in history in terms of the destructions of the First and Second Temples (Maybaum), while another would contextualise it by reference to the giving of the Law at Mount Sinai and the Exodus story (Fackenheim), while a third would twin it with the establishment of the State of Israel (Berkovits). Such discrepancies would seem almost inevitable. One has little choice but to regard their various selections of significant moments within Jewish history as essentially arbitrary, and to remain highly suspicious of the rationales presented for why one particular selection of events is more useful for demonstrating God's intervention in history than another. It may be true of history that God is pulling the strings behind the scenes, and that certain events are linked together in ways that reveal His purposes. But in terms of the evidence, there is no obvious way to demonstrate such a claim conclusively, one way or the other. One might as easily use the raw data of history to construct a world where demonic, rather than divine, forces dominate. ${ }^{52}$

Furthermore, this idea that we can take an historical event, the Holocaust, and find the footsteps of God in its ashes, represents a serious challenge to the modus operandi of modern historians, and of modern theologians, too, in many cases. The rationalist, naturalist assumptions that have characterised the study of history in the west for two centuries have convinced liberal-minded Jewish and Christian theologians to be very cautious about using the past as evidence for God's active engagement in the world, and even to refrain from so doing. ${ }^{53}$ The question is not whether the method is flawed, since historians also make highly subjective editorial selections of historical events to construct plausible narratives of the past. It is rather the newfound confidence that supernatural causes can and should be regarded as causal factors in explaining the historical events. The Holocaust, as an event that frustrates easy analysis of any sort, seems to have enticed a number of religious thinkers to reconsider the modernist position and to seek to demonstrate the divine presence in history from a post-Holocaust perspective.

All this is reminiscent of another debate, a debate that is not about God's interaction with human history but rather about His interaction with natural history. Before the advent of Darwin's theory 
of evolution by natural selection, a common view was that God had specially created the different species and variety of life. For many theists, Natural Theology held the beguiling promise that the sensitive observer could learn much about the Creator's character and will from the book of nature; its harmony, beauty and order seemed to reflect the mind of a God worthy of our adoration. After Darwin, the impulse to draw lessons about the divine character directly from observation of nature became less appealing. After all, the new vision of nature was of a wasteful, cruel, competitive, directionless process. Most species have become extinct, and while there is symbiosis and cooperation, there is also fierce competition between and within species, what Darwin called the 'war of nature': most organisms never attain sexual maturity and are, along with the few organisms that survive to old age, finished off by predators or parasites. To the casual observer, disinclined to perform the theological gymnastics required to conclude otherwise, nature seemed shockingly unjust and full of meaningless suffering. To continue to believe that propositions about God could be drawn from nature but should focus only on its harmony, beauty and order seemed downright perverse. Natural Theology fell from grace, so to speak, and has never recovered the ground it lost since the early to mid nineteenth-century. Since then thoughtful Christians and Jews have spoken in somewhat vague terms about the evolutionary process as the means by which God created the diversity of life. Now, it may be true that the natural laws of evolution (perhaps even the mechanisms of Darwinian natural selection) are guided by God in some mysterious fashion. ${ }^{54}$ But the point is that whereas before the Darwinian revolution God functioned as the causal agent, after Darwin there was no longer a gap for a God-of-the-gaps to fill. God's influence upon the development of life certainly could not be falsified, as Darwin himself acknowledged, but it was no longer necessary to bring Him into the equation in order to explain the natural history of the biodiversity that surrounds us.

While it is certainly possible that there are higher levels of explanation for both natural and human history and that God guides the directions in which they develop, yet it seems only prudent that we should accept the logical possibility of divine intervention in human affairs, the nature of which we cannot fathom, and then set it 


\section{Electronic Offprint}

to one side and concentrate on the naturalistic alternatives. The argument is a purely pragmatic one. Put simply: talk of supernatural causation has a tendency to stifle the development of knowledge of human history, as of natural history. Thus our theologians appear to go too far when, in their desperate concern to offer some kind of redemptive interpretation of the Shoah, they assert that it provides evidence for God's presence in history, and specifically, Jewish history as viewed from the perspective of Auschwitz.

One way of getting around the problem is illustrated by the most recent contribution to Holocaust Theology, that of the British Orthodox feminist, Melissa Raphael (1960-), the author of The Female Face of God in Auschwitz (2003). Raphael does not claim to see history as the working out of a divine plan, or the Holocaust as having any part of such a grand scheme. ${ }^{55}$ She does, however, talk of God's presence at Auschwitz in a way that, at first sight, appears to share much in common with Fackenheim's theology. Her particular approach is to begin by noting that, in a careful selection of female camp testimony, the idea of ritual cleanliness often seems to be associated with God. For example,

Charlotte Delbo was first able to make a (prohibited) attempt to wash herself in a freezing stream sixty-seven days after entering Auschwitz. As she took off her clothes she found that her toe nails had detached themselves from her toes and stuck to the insides of her stockings. Her pubic hair and underpants were 'stiff' with dry diarrhoea ... One girl in a ghetto camp lamented the lack of facilities for washing and disposing of picked lice [reporting]: 'we used to squeeze the lice with our clothes, which caused the latter to become damp and stick to our bodies.' Significantly, [the girl] adds, 'We literally lost the image of God'. ${ }^{56}$

Raphael also tentatively asserts that women's experiences in the camps were often more cooperative than was the case among men, and emphasises the importance in survivor testimony of the little acts of loving-kindness upon which camp-sisters so depended for their dignity and self-worth. ${ }^{57}$ She then suggests that Lurianic Jewish mysticism, with its conception of a broken God whose divine sparks need to be restored to the godhead, can serve as a 'narrative theological framework' for exploring the meaning and significance of 
such behaviour. And she finds further support for this from the survivor accounts. For example,

To be washed could be to be resurrected. Livia Bitton-Jackson remembers how, during a brief respite from Auschwitz in 1944, a forced labour factory in Augsberg provided her with clean white sheets on her bunk, soap, showers whose flow of water could be controlled, and clean towels. The experience was more than merely pleasurable, it was a restoration of the holy to self and world. Her joy is couched in the language of Jewish mystical theology [says Raphael, quoting the one testimony]: 'As we get out of the showers, a secret spark of self-esteem is nurtured deep within. ${ }^{58}$

Such testimonies of the image of God's face, and the nurturing of divine secret sparks, lead Raphael finally to the shekhinah, that is, the dwelling presence of God (traditionally associated with the revelations at the burning bush, Mount Sinai and in the Tabernacle in the wilderness), which she observes is feminine in Hebrew and which she describes as 'the love of the Mother-God'. ${ }^{59}$ All this results in a portrayal of God as a God who cares for Her children and who, ultimately, shares in their suffering.

Raphael's approach certainly succeeds in avoiding the problematic engagement with history and the historical process that has dogged previous theologies of the Shoah. She makes no pretence at a rational justification for why one pattern of historical moments is to be regarded as more revelatory than another. In her search for redemptive meaning or the divine presence, she explains that 'Theology is not a purely evidential project, but must attend to a distinctive and ancient patterning of signs'. ${ }^{60}$ She admits that these 'signs' of the enduring power and presence of redemptive love must be salvaged against a mountain of contradictory, conflicting evidence. For Raphael, this is an act of faith despite and independent of history, rather than an assertion that history itself leads to this conclusion. On the one hand, she does not feel obliged to claim that the Holocaust is unique; while horrified by the event, she does not claim that it is incomprehensible. On the other, there is nothing in her writing to assume that anything other than naturalistic explanations were at play in the work of the perpetrators and the victims, and she does not need to incorporate the Shoah into a pattern of providential 


\section{Electronic Offprint}

historical events in order to trace the divine presence in the camps. At the same time, Raphael also appears to succeed in retaining an immanent God, a God whose presence can be felt, in contrast to the philosophical and mystical conceptions of the deity offered by those like Cohen, Rubenstein and Jonas. This, after all, is the whole point of locating the divine amongst those camp sisters who cared for each other. And yet Raphael's God, described in the language of biblical and mystical Jewish tradition, and heavily dependent upon an imaginative interpretation of the testimonies of female survivors, is, in the end, an abstraction of social relations and human dignity as experienced among a small number of victims of Nazism. It is a literary construction woven from the tattered testimonies of women who did not understand their experience spiritually as she does. Unlike Fackenheim, for example, Raphael does not base her theology on the God who saved His children from Egyptian slavery and issued the Law at Sinai (or who recently disclosed His revelatory will at Auschwitz). If her God is the personification of the acts of lovingkindness of female camp inmates, then She has had no more tangible impact upon history than an afterthought. In the last analysis one must question whether such a God is real enough for Her presence to be felt in any meaningful sense.

\section{The Holocaust and the Question of a Historically-situated Judaism}

Finally, we turn to the question of Judaism and the nature of its relationship to history and how, if at all, engagement with the historical event of the Shoah has altered the theologians' understanding of the religion itself. This question boils down to: Does the historical reality of Auschwitz have unique theological implications for Judaism?

Rubenstein, Fackenheim and Raphael are among those who claimed that the traditional conceptions of Judaism need to be reformulated or even modified. Rubenstein's declaration that the God of Tradition was dead actually generated a theology of community that prized a demythologised Judaism as the means by which to achieve Jewish solidarity in an empty universe; as he put it, 'It is precisely because human existence is tragic, ultimately hopeless, and without meaning that we treasure our religious community.' ${ }^{61}$ 


\section{Electronic Offprint}

Fackenheim's belief that a commanding voice was heard from Auschwitz was not only socially revolutionary, in that the renewal of commitment of the Jewish people to live as Jews is valid whether they define themselves as religious or not, but was also profoundly political, since it demands political support for the State of Israel which Fackenheim regards as the only practical means by which the commandment can be honoured. ${ }^{2}$ For Raphael, the Holocaust leaves us in a place where traditional, patriarchal Jewish attitudes towards women cannot be left unchallenged. She calls for a revision of Jewish thought and practice, arguing that, 'In memory of Nazism's denial of the full humanity of Jews, Jewry should repudiate those gynophobic textual and practical inheritances that enshrine as Torah the defamation, derogation of, or discrimination against women. ${ }^{63}$ Of course, such calls for reform are not always made, as the case of Berkovits shows, since for this Orthodox thinker, the traditional resources are adequate - he can develop a free-will defence from the biblical image of God's hiddenness - and no new theological implications are raised. Nevertheless, it is not an uncommon claim and in 1988 the Orthodox rabbi Norman Solomon wrote a very thoughtful essay which scrutinised the reasons why this might so often be proposed. ${ }^{64} \mathrm{He}$ argued that it was modernity, rather than the Shoah, which had provoked the 'theological ferment' and had led to a loss of confidence in traditional theology. The Holocaust, he suggested, simply provided thinkers with an opportunity to debate the inadequacies of traditional solutions to the problem of evil that had either always been inadequate, or which were no longer regarded as viable, such as the hope in life after death. Along with the loss of belief in the inerrancy of scripture and the unquestioned authority of religious institutions, the Enlightenment and modernity more generally had, said Solomon, brought about a conviction that religious teachings were shaped by historical context and that religious truth was historically situated. ${ }^{65}$ Let us consider one more example of a Holocaust Theologian before taking Solomon's discussion forward.

Irving Greenberg (1933-) is an interesting case. As an Orthodox Jewish rabbi, one might well have expected him, like Berkovits, to be committed to an unchanging essence of Judaism, even if this is an essence that required fresh expression each generation. In fact, in a seminal article entitled 'Cloud of Smoke, Pillar of Fire', published in 


\section{Electronic Offprint}

1977, he argues that the Holocaust poses several mortal challenges to Judaism, including the belief in God, the covenant, redemption and the value of human life. Among other things, the level of destruction suggested that the traditional meaning of the Covenant was in tatters and needed rethinking. If two-thirds of European Jewry and almost the entire world of the yeshivot or centres for Jewish religious learning had gone, then what did that say about the traditional conceptions of a redemptive God who acted in history and promised redemption to the people with whom He was in covenant? Likewise, Judaism (and Christianity) believed that man was made in God's image, and it followed from this that in Judeo-Christian culture, human life was of great value. Greenberg, who, incidentally, was trained as a historian, uses a court transcript from the Nuremberg Trials to make his point that one could not, after the camps, be so confident about such an assertion. The transcript reads:

WITNESS: ...women carrying children were [always] sent with them to the crematorium. The children were then torn from the parents outside the crematorium and sent to the gas chambers separately. When the extermination of the Jews in the gas chambers was at its height, orders were issued that children were to be thrown straight into the crematorium furnaces, or into a pit near the crematorium, without being gassed first.

RUSSIAN PROSECUTOR: How am I to understand this? Did they throw them into the fire alive, or did they kill them first?

WITNESS: They threw them in alive. Their screams could be heard at the camp. It is difficult to say how many children were destroyed in this way.

RUSSIAN PROSECUTOR: Why did they do this?

WITNESS: It's very difficult to say. We don't know whether they wanted to economise on gas, or because there was not enough room in the gas chambers. ${ }^{66}$

Greenberg makes the calculation to show that, in historical fact, a child created in the image of God had a value of around two-fifths of a cent in 1944. If, as he had believed, 'Judaism and Christianity ... stand or fall on their fundamental claim that the human being is ... of ultimate and absolute value', ${ }^{67}$ and if the historical record so comprehensively illustrated the frailty of such a belief, the ease with 
which such a belief could be cast aside, then one could hardly go on as if nothing had changed. Greenberg's point is that such central conceptions of Judaism would have to be reformulated if Judaism was to survive. How hollow, otherwise, would any future talk of creation, covenant or redemption, sound? As he put it, 'Let us offer, then, as a working principle the following: no statement, theological or otherwise, should be made that would not be credible in the presence of burning children. ${ }^{68}$ If a reorientation towards core beliefs was so necessary, then one could no longer cling to a traditional, unchanging conception of Judaism. Greenberg's was therefore a recognition of the historically-situated character of Jewish religious belief. In Greenberg's case, this reorientation was to reject any sense of assurance or certainty in one's religious life, and to view Judaism as essentially a voluntary endeavour, now that God's moral authority had been so seriously undermined. In a post-Holocaust world, an easy faith was untenable, and what remained was a dialectic of faith and uncertainty. One could, one should, live a life of faith that was always in crisis, always haunted by doubt. Anything else was unacceptable; as he saw it: 'Living in the dialectic becomes one of the verification principles for alternative theories after the Holocaust. ${ }^{69}$

Looking back over most of the theologies considered in this article, a frequent claim has been that a new kind of theology is necessary after Auschwitz. This is true even to the extent that thinkers such as Greenberg, whose conservative religious commitments might have assumed the unchanging nature of Jewish religious truth, have come to view it as a religion that can and should be modified as a result of historical happenstance. What is interesting, and what supports Norman Solomon's suspicion that it is modernity, rather than the Holocaust specifically, which has led to this situation, is the fact that none of these revisions have actually required the Shoah in order to be articulated well before the rise of Holocaust Theology. Ignaz Maybaum's interpretation of Jewish suffering as the mechanism by which humanity achieves spiritual progress can be traced back to classic Reform formulations of the Mission of Israel in the nineteenth century. ${ }^{70}$ Richard Rubenstein's declaration of the death of the God of Tradition and demythologising of the People of Israel in 1966 had been foreshadowed most obviously by Mordechai Kaplan's claim in 1934 that Judaism was a

Copyright (C) 2011 Vallentine Mitchell 


\section{Electronic Offprint}

civilisation that no longer needed to legitimise itself in supernaturalist terms. $^{71}$

The feminist programme of reform called for in the most recent contribution by Raphael in 2003 had hardly had to wait for the Holocaust. ${ }^{72}$ Likewise, Fackenheim's conviction that Jews should live as Jews and Zionists did not logically require the lesson of the Shoah..$^{73}$ Arguably, some of the authors themselves were espousing similar reconstructions of Judaism before they wrote about the Shoah, including Greenberg who ostensibly attained his realisation of the historical character of religious belief as a result of engaging with the Holocaust. Earlier writings ${ }^{74}$ show that the Orthodox rabbi had previously propounded a conception of Judaism in which he appeared to undermine the divine authority that underlay the traditional conception of commandment. Drawing lessons from contemporary culture and history, he had suggested in 1969:

Our voluntaristic society [i.e. US democracy] has demonstrated an extraordinary capacity to elicit loyalty and sacrifice from its people ... Clearly people identify most strongly with laws which they feel they have voluntarily accepted ... [Therefore] we should educate Jews to accept mitzvot [commandments] freely. Rational deliberation regarding the significance of any practice is essential: this is a restoration of the dialectic of freedom and authority. ${ }^{75}$

The voluntary nature of the Covenant is thus supported in terms of the pragmatics of liberal democracy well before he engaged with the Holocaust, while afterwards the same argument is presented as if it flowed from the challenges that the Holocaust posed to the traditional certainties of Jewish faith.

The suggestion made here, then, is that theological positions held by these theologians are not only coherent and attainable without reference to the Holocaust, but, on occasion, were even proposed beforehand by the same thinkers. It seems that despite the impression given, the Holocaust frequently functions merely as a rhetorical device. Its moral authority and power make it attractive as a peg upon which to hang one's ideology, one's existing theological reformulations of Judaism, but it has not, in fact, in itself brought about the profound changes to Judaism that are sometimes attributed to it. 


\section{Conclusion}

What should one conclude from this discussion of the way in which history is approached by Holocaust Theologians? In response to the claim that the Holocaust was a unique, inexplicable event, beyond the reach of historical enquiry, it was suggested that it is not only ethically dangerous to remove the Holocaust from history, but that the problem largely lies in a mistaken belief that we cannot understand the behaviour of those involved, and an assumption that any event that can threaten the survival of Judaism must be unparalleled and quite beyond our ken. In response to the claim that the Holocaust provides dramatic evidence of God's action in history, we have considered several examples of grand sweeping narratives of Jewish history and revelatory moments, and concluded that these examples, at least, extrapolate well beyond the historical evidence from which they are constructed. In this context, we have seen that redefining God in terms of human activity is one way to avoid some of the difficulties facing those who insist on a supernatural God-who-acts-in-history, although, like philosophical and mystical conceptions of the divine, such an approach produces an abstract or transcendent sense of God rather than an immanent one. Finally, we have questioned the claim that the Holocaust, as an historical event, demands profound changes in Judaism. Within Holocaust Theology, the Shoah tends to function as a rhetorical device to justify calls for reform or reorientation within Jewish religion or identity, calls which actually have their roots in the modern realisation of the historical-situatedness of religion and religious tradition more generally.

\section{NOTES}

1. These three claims are by no means exhaustive; Katz has offered nine kinds of Jewish religious response, although they do not all involve explicit engagement with history per se. Katz, Post-Holocaust Dialogues, 144.

2. Some well-known examples include Paul van Buren, Alice and Roy Eckhardt, and Franklin Littell. Van Buren, Discerning the Way; Van Buren, A Christian Theology of the People Israel; Van Buren, Christ in Context; Eckardt and Eckardt, Long Night's Journey into Day; Littell, The Crucifixion of the Jews. For a discussion of Christian Holocaust Theology, see Haynes, Prospects for Post-Holocaust Theology.

3. A recently published collection of Jewish responses to the Shoah includes a number of ultra-Orthodox Jewish works written from the time of the catastrophe. Katz, Biderman and Greenberg, Wrestling with God. 


\section{Electronic Offprint}

4. Historical investigation might be described as scientific in the sense that it attempts to be systematic by sifting through the evidence to provide a wide accumulation of facts. It is not scientific, however, in the sense of being deductive, nor can it claim powers of prediction. And, of course, it is only in very recent times that historians have sought to eliminate supernatural, or at least supranatural, causes.

5. 'Men shun the scandal of the particularity of Auschwitz. Germans link it with Dresden; American liberals, with Hiroshima. Christians deplore anti-Semitism-in-general, while Communists erect monuments of victims-of-Fascism-in-general, depriving the dead of Auschwitz of their Jewish identity even in death. Rather than face Auschwitz, men everywhere seek refuge in generalities, comfortable precisely because they are generalities. And such is the extent to which reality is shunned that no cries of protest are heard even when in the world community's own forum obscene comparisons are made between Israeli soldiers and Nazi murderers.' Fackenheim, The Jewish Return into History, 26.

6. In particular, the Jew must 'refuse to dissolve Auschwitz into suffering-in-general, even though he is almost sure to be considered a Jewish particularist who cares about Jews but not about mankind'. Ibid., 27.

7. In an appeal to Christian readers, Fackenheim suggests that the 'scandal of particularity' regarding the uniqueness of the Holocaust could be compared to early Christian claims regarding the death and resurrection of Christ in the face of similar pagan claims. Ibid., 133.

8. Ibid., 27.

9. Cohen, The Natural and the Supernatural Jew, 304.

10. Cohen, The Tremendum, 1, 8-10.

11. Otto and Harvey, The Idea of the Holy. First published in German as Otto, Das Heilige.

12. Cohen, The Tremendum, 17-19.

13. Ibid., 1-2.

14. 'It is time now to build a bridge over the abyss of the tremendum. It is a bridge that spans the abyss but does not observe it. Wayfarers upon the bridge, however its moorings in the past of the Jewish People, and its future in the prospect of its ongoing life, cannot neglect the obligation to look over into the chasm beneath. They know the abyss but, since they pass along the bridge, they know equally that they do not have their being in its depths; however much the ineffaceable abyss informs them, their own being and proper life is elsewhere - on the bridge, in fact, over the abyss.' Ibid., 82 .

15. Ibid., 7-10, 39, 45.

16. Cited in Reichek, 'Elie Wiesel: Out of the Night', 42.

17. Cited by Shea, 'Debating the Uniqueness of the Holocaust', A7.

18. Wiesel, A Jew Today, 188.

19. Bauer, 'Is the Holocaust Explicable?', 145.

20. Ibid.

21. Ibid., 145. The paper was first read at the 'Remembering for the Future' conference at Oxford, July 1988.

22. Ibid., 147.

23. Ibid., 147, 148.

24. Cohen, The Tremendum, 82.

25. 'If I told you that I believed in God, I would be lying; if I told you that I did not believe in God, I would be lying.' E. Wiesel in conversation, cited in Rubenstein and Roth, Approaches to Auschwitz, 285.

26. Maybaum, The Face of God after Auschwitz, 61-4.

27. He goes on, 'We remain loyal to the citizens of Israel; they need us, and we shall not fail them. But we now realise that our Holy Land is not a country on the shores of the Mediterranean. We now realise that our Holy Land is mankind's future. Mankind's 
future and nothing else is our goal. As Jews we serve mankind. Our exodus from the Middle Ages is assured. We re-enter history in the joy of still having the privilege of serving the old mission, in the joyful knowledge that the unchanging and unending kindness of God accompanies us in this mission.' Ibid., 68.

28. 'Of Nebuchadnezzar, the destroyer of Jerusalem, the word of God in the book of Jeremiah says "Nebuchadnezzar, My Servant" ... Would it shock you if I were to imitate the prophetic style and formulate the phrase: Hitler, My Servant?!' Ibid., 67.

29. Ibid., 52.

30. Ibid., 36.

31. Ibid., 200.

32. For example, Bernard Maza explores the idea that the Holocaust was the divine reaction to the search of Jewish youth for new values such as socialism and secular Zionism in Eastern Europe, and materialism in North America. It resulted, in Maza's mind, with a widespread return to Torah-observant Judaism. Maza, With Fury Poured Out, 124-7.

33. 'I - Berish, Jewish innkeeper at Shamgorod - accuse Him of hostility, cruelty and indifference. Either He dislikes His Chosen People or He doesn't care about them - period! But then, why has He chosen us - why not someone else for a change? Either $\mathrm{He}$ knows what's happening to us, or He doesn't wish to know! In both cases He is ... He is ... guilty! Yes, guilty ... If He insists upon going on with His methods, let Him - but I won't say Amen. Let Him crush me, I won't say Kaddish. Let Him kill me, let Him kill us all, I shall shout and shout that it's His fault. I shall use my last energy to make my protest known. Whether I live or die, I submit to Him no more ... I lived as a Jew, and it is as a Jew that I shall die - and it is as a Jew that, with my last breath, I shall shout my protest to God! And because the end is near, I shall shout louder! Because the end is near, I'll tell Him that He's more guilty than ever.' Wiesel, The Trial of God, $125,133,156$.

34. Blumenthal, Facing the Abusing God.

35. Cohen, The Tremendum, 97-8.

36. Ibid., 97.

37. Rubenstein, After Auschwitz, 223.

38. 'I believe there is a conception of God ... which remains meaningful after the death of God-who-acts-in-history. It is a very old conception of God with deep roots in both Western and Oriental mysticism. According to this conception, God is spoken of as the Holy Nothingness. When God is so designated, he is conceived of as the ground and source of all existence. To speak of God as the Holy Nothingness is not to suggest that he is a void. On the contrary, he is an indivisible plenum so rich that all existence derives from his very essence ... Why then the term Nothingness? ... The infinite God, the ground of all finite beings, cannot be defined ... The infinite God is nothing ... It is also helpful to note that whoever believes God is the source or ground of being usually believes that human personality is coterminous with the life of the human body. Death may be the entrance to eternal life ... but it involves the dissolution and disappearance of individual identity ... Perhaps the best available metaphor for the conception of God as the Holy Nothingness is that God is the ocean and we are the waves. In some sense each wave has its moment in which it is distinguishable as a somewhat separate identity. Nevertheless, no wave is entirely distinct from the ocean which is its substantial ground.' Rubenstein, Morality and Eros, 185-6.

39. Jonas, 'The Concept of God after Auschwitz', 473.

40. Ibid., 472. In a later revision of the article, Jonas was more explicit still: 'Not because he [God] chose to, but because he could not intervene did he fail to intervene.' Jonas and Vogel, Mortality and Morality, 140.

41. Berkovits, With God in Hell, 83.

42. Berkovits, Faith after the Holocaust, 61. 


\section{Electronic Offprint}

43. Ibid., 156.

44. 'To curb the use of [divine] power where infinite power is at hand, to endure the mocking of one's enemies when one could easily eliminate them, that is true strength ... God is mighty, for He shackles His omnipotence and becomes "powerless" so that history may be possible.' Ibid., 109.

45. 'That man may be, God must absent Himself; that man may not perish in the tragic absurdity of his own making, God must remain present. The God of history must be absent and present concurrently. Thus, many find Him even in His "absence"; many miss Him even in His presence. Because of the necessity of His absence, there is the "Hiding of the Face" and suffering of the innocent; because of the necessity of His presence, evil will not ultimately triumph.' Ibid., 107.

46. Fackenheim, God's Presence in History, 9.

47. Ibid., 8-9.

48. Fackenheim, 'Jewish Faith and the Holocaust', 32.

49. Fackenheim, The Jewish Return into History, 23-4.

50. Fackenheim, God's Presence in History, 9.

51. The so-called 'empiricist falsifiability thesis' is discussed in the context of Rubenstein's writings in Katz, Post-Holocaust Dialogues, 179-80.

52. One Christian theologian, A. Roy Eckardt, has done exactly this, by explaining the lachrymose history of the Jews as a history shaped by the devil; his rationale is that antisemitism, the engine of Jewish history, has not been adequately explained by rational enquiry and only makes sense if it is regarded as essentially demonic in nature. Eckardt and Eckardt, Long Night's Journey into Day, 51-5.

53. Fackenheim himself has addressed this issue, suggesting that for Jewish tradition, at least, God is not a hypothesis to be confirmed or denied in relation to 'evidence' such as amassed by historians. This idea of a category error is a central premise to Fackenheim, Encounters between Judaism and Modern Philosophy. Others, of course, would disagree. For a useful overview of the ways in which rationalist historicism has profoundly shaped Christian theology, specifically, in the last two centuries, see Davaney, Historicism. For a brief discussion of the impact of historicism upon Jewish thought (in the context of nineteenth-century Jewish New Testament studies), see Langton, The Apostle Paul in the Jewish Imagination, 31-40.

54. It is worth noting that most have ignored the Darwinian conception of evolution by natural selection, which is directionless, and have insisted on a theory that stresses direction such as Lamarckianism or orthogenesis. For an excellent introduction to these competing theories, see Bowler, Evolution, 236-50.

55. In fact Raphael is highly critical of such patriarchal conceptions of the divine sovereign that require Him to demonstrate His power and dominion over the wicked. Raphael, The Female Face of God in Auschwitz, 33-7.

56. Ibid., 65, 64.

57. 'In Auschwitz-Birkenau when a women lifted her cast down face to the summons of her mother, daughter, sister, or friend it caught the reflected light of the Shekhinah on its upturned surface, reflecting the glory or kavod of God's face back into the world even a world which was, for them, over, and a world which, become Auschwitz, had turned God away at the gates. The relational moment offered no more than a dedication to peace. Yet even the dimmest illumination of one suffering face by the facing, seeing, other produced the intimation of God's radiance (kavod) among them. Rabbinic midrash compares the Shekhinah or divine presence to light, to what shines. "Washed" by ersatz coffee, urine, brackish water or love alone, the reflective face lit God's way into, through and out of, Auschwitz.' Ibid., 105-6.

58. Ibid., 69.

59. Ibid., 117-18. 


\section{Electronic Offprint}

60. Ibid., 9 .

61. Rubenstein, After Auschwitz, 68.

62. 'Only by virtue of a radical "secular" self-reliance that acts as though the God who once saved could save no more can even the most "religious" survivor hold fast either to the sinaitic past or to the messianic future. And only by virtue of a radical "religious" memory and hope can even the most "secularist" survivor rally either the courage or the motivation to decide to remain a Jew, when ever natural impulse tempts him to seek forgetfulness and safety elsewhere ... Except only for those who never became part of the modern world, all religious Israelis are willing, if required, to take up "secular" arms in defence of the state. And except for those who cannot extricate themselves from ideologies that do Jewish history no justice, all secular Israelis have the "religious" wish that the state be Jewish.' Fackenheim, Encounters between Judaism and Modern, 167.

63. 'It should also not be forgotten that Jewish women are also traditionally cast as sources of ritual uncleanness. Jewish naming of the Nazi calumny against Jewish personhood should therefore be morally reflexive. In the light of Nazi Germany's racist abuse of the religio-moral concept of purity, Israel - the body was cast as the contaminant of Aryan space - must particularly revisit its own perception of the niddah (menstruant) as a contaminant. Where the tradition is gynophobic it diminishes the Nazi crime, lending its isolation and destruction of Jewish bodies, especially women's bodies, the vocabulary and worse, the ontology, of religious purification. Never again should the rabbinic description of a woman as 'a pitcher full of filth [excrement] with its mouth full of blood' (Shabbat 152a) pass without censure. Traditional Judaism must listen again to the words "Women are a separate people" (Shabbat 62a) because after European Jewry was set apart for destruction in camps and ghettos those words cannot mean whatever they might have done before 1933.' Raphael, The Female Face of God in Auschwitz, 77.

64. Solomon, 'Jewish Responses to the Holocaust'.

65. Ibid., 21-3.

66. S. Szmaglewska in Trial of the Major War Criminals before the Military Tribunal (Nuremberg 1947-49), cited in Greenberg, 'Cloud of Smoke, Pillar of Fire', 3-4.

67. Ibid., 9.

68. Ibid., 23.

69. Ibid.

70. For example, the German-born radical reform leader in the US, David Einhorn, commented at the Rabbinic Conference in Frankfurt, 1845: 'The loss of political independence was bewailed formerly as a misfortune, but in reality this loss was really progress and entailed not a cramping, but an expansion, of the religious spirit. Israel approached nearer the fulfillment of its mission. Devotion took the place of sacrifice. From Israel's midst God's word was to be carried to all portions of the earth.' Cited in Philipson, The Reform Movement in Judaism, 248.

71. Kaplan, Judaism as a Civilization.

72. Jewish feminism in its modern form is a phenomenon of the 1970 s, but expressions of proto-feminist reformulations of Judaism can be found much earlier. A striking example is the Anglo-Jewish theologian, novelist and poet Grace Aguilar (1816-47) who privileged women's spirituality over traditional Jewish learning in The Spirit of Judaism (1842) and The Jewish Faith (1846). For an overview of Aguilar's remarkable body of work, see Aguilar and Galchinsky, Selected Writings.

73. The classic rationales for modern political Zionism and the normalisation of Jewish life within a nation state as the only viable solution to antisemitism were articulated in Leon Pinsker's 'Auto-Emancipation' (1882) and Theodore Herzl's 'A Solution to the Jewish Question' (1896). 


\section{Electronic Offprint}

74. For an in-depth discussion of the development of Greenberg's thought, see Morgan, Beyond Auschwitz, 126. Morgan himself does not make this explicit point.

75. Greenberg, 'Change and the Orthodox Community', 62, 65.

\section{REFERENCES}

Aguilar, Grace and Michael Galchinsky, Selected Writings (Orchard Park, NY: Broadview Press, 2003).

Bauer, Yehuda, 'Is the Holocaust Explicable?' Holocaust Genocide Studies 5, no.2 (1990): $145-55$.

Berkovits, Eliezer, Faith after the Holocaust (New York: KTAV Publishing House, 1973).

Berkovits, Eliezer, With God in Hell: Judaism in the Ghettos and Deathcamps (New York and London: Sanhedrin Press, 1979).

Blumenthal, David R., Facing the Abusing God: A Theology of Protest (Louisville, KY: Westminster/John Knox Press, 1993).

Bowler, Peter J., Evolution: The History of an Idea, 3rd ed. (Berkeley, CA: University of California Press, 2003).

Cohen, Arthur Allen, The Natural and the Supernatural Jew: An Historical and Theological Introduction (New York: Pantheon Books, 1962).

Cohen, Arthur Allen, The Tremendum: A Theological Interpretation of the Holocaust (New York: Crossroad, 1981).

Davaney, Sheila Greeve, Historicism: The Once and Future Challenge for Theology (Minneapolis, MN: Fortress Press, 2006).

Eckardt, A. Roy and Alice Eckardt, Long Night's Journey into Day: Life and Faith after the Holocaust (Detroit, MI: Wayne State University Press, 1982).

Fackenheim, Emil L., 'Jewish Faith and the Holocaust: A Fragment', Commentary (1968): 30-6.

Fackenheim, Emil L., God's Presence in History: Jewish Affirmations and Philosophical Reflections, The Deems Lectures, 1968 (New York: New York University Press, 1970).

Fackenheim, Emil L., Encounters between Judaism and Modern Philosophy: A Preface to Future Jewish Thought (New York: Basic Books, 1973).

Fackenheim, Emil L., The Jewish Return into History: Reflections in the Age of Auschwitz and a New Jerusalem (New York: Schocken Books, 1978).

Greenberg, Irving, 'Change and the Orthodox Community', Response 7, no.1 (1969): 14-21.

Greenberg, Irving, 'Cloud of Smoke, Pillar of Fire: Judaism, Christianity and Modernity after the Holocaust', in Auschwitz: Beginning of a New Era?: Reflections on the Holocaust, ed. Eva Fleischner (New York: Ktav, 1977): 7-55.

Haynes, Stephen R., Prospects for Post-Holocaust Theology (Atlanta, GA: Scholars Press, 1991).

Jonas, Hans, 'The Concept of God after Auschwitz', in Out of the Whirlwind: A Reader of Holocaust Literature, ed. Albert H. Friedlander (New York: Union of American Hebrew Congregations, 1968): 464-76.

Jonas, Hans and Lawrence Vogel, Mortality and Morality: A Search for the Good after Auschwitz (Evanston, IL: Northwestern University Press, 1996).

Kaplan, Mordecai Menahem, Judaism as a Civilization: Toward a Re-Construction of American-Jewish Life (New York: Macmillan Co., 1934).

Katz, Steven T., Post-Holocaust Dialogues: Critical Studies in Modern Jewish Thought (New York and London: New York University Press, 1983).

Katz, Steven T., Shlomo Biderman and Gershon Greenberg, Wrestling with God: Jewish 
Theological Responses During and after the Holocaust (Oxford and New York: Oxford University Press, 2007).

Langton, Daniel R., The Apostle Paul in the Jewish Imagination: A Study in Modern JewishChristian Relations (New York: Cambridge University Press, 2010).

Littell, Franklin H., The Crucifixion of the Jews (New York: Harper \& Row, 1975).

Maybaum, Ignaz, The Face of God after Auschwitz (Amsterdam: Polak \& Van Gennep, 1965).

Maza, Bernard, With Fury Poured Out (Hoboken, NJ: KTAV, 1986).

Morgan, Michael L., Beyond Auschwitz: Post-Holocaust Jewish Thought in America (Oxford and New York: Oxford University Press, 2001).

Otto, Rudolf, Das Heilige: Über das Irrationale in der Idee des Göttlichen und sein Verhältnis zum Rationalen (Breslau: Trewendt und Granier, 1917).

Otto, Rudolf and John Wilfred Harvey, The Idea of the Holy: An Inquiry into the NonRational Factor in the Idea of the Divine and Its Relation to the Rational (London: Oxford University Press, 1923).

Philipson, David, The Reform Movement in Judaism (London and New York: Macmillan, 1907).

Raphael, Melissa, The Female Face of God in Auschwitz: A Jewish Feminist Theology of the Holocaust (London: Routledge, 2003).

Reichek, Morton A., 'Elie Wiesel: Out of the Night', Present Tense 3, no.3 (1976): 41-7.

Rubenstein, Richard L., After Auschwitz: Radical Theology and Contemporary Judaism (New York: Macmillan, 1966).

Rubenstein, Richard L., Morality and Eros (New York: McGraw-Hill, 1970).

Rubenstein, Richard L. and John K. Roth, Approaches to Auschwitz: The Holocaust and Its Legacy (Atlanta, GA: John Knox Press, 1987).

Shea, Christopher, 'Debating the Uniqueness of the Holocaust', Chronicle of Higher Education (31 May 1996): A7-A8.

Solomon, Norman, 'Jewish Responses to the Holocaust', in An Address to the Consultation of the Anti-Defamation League of Bnai Brith and the Polish Bishops' Conference (Birmingham: Centre for the Study of Judaism and Jewish/Christian Relations, 1988).

Van Buren, Paul Matthews, Discerning the Way, A Theology of the Jewish Christian Reality (San Francisco, CA and London: Harper \& Row, 1980).

Van Buren, Paul Matthews, A Christian Theology of the People Israel, A Theology of the Jewish Christian Reality (San Francisco, CA and London: Harper \& Row, 1987).

Van Buren, Paul Matthews, Christ in Context, A Theology of the Jewish Christian Reality (San Francisco, CA and London: Harper \& Row, 1988).

Wiesel, Elie, A Jew Today (New York: Random House, 1978).

Wiesel, Elie, The Trial of God (as It Was Held on February 25, 1649 in Shamgorod): A Play in Three Acts (New York: Random House, 1979). 